\title{
Role of Educational Qualification of Consumers on Need Recognition: A Study with Reference to Car
}

\author{
Dr. S. Prem Kumar \\ Associate Professor, Department of Sports Management, Tamil Nadu Physical Education and Sports University, \\ Chennai-600 127, India.
}

\begin{abstract}
Demographic variables are the most popular bases for segmenting the customer groups. One reason is that consumer needs, wants, preferences and usage rates often highly associated with demographic variables. Another is that demographic variables are easier to measure than the most of other type variables. Marketers are keenly interested in the size and growth rate of population in different cities, regions, nations; age distribution; educational levels; household patterns; and regional characteristics and movements. Because, on the basis of these measures only, marketers have to formulate their marketing strategies in order to fulfil the needs, wants and preferences of consumers. Moreover, demographic variables make known the ongoing trends, such as shifts in age, sex and income distribution that signal new business opportunities to the marketers. Demographic trends are highly reliable for the short and intermediate run. This paper, with a strong backing of literature, explains the role of educational qualification of consumers on recognizing a need for car.
\end{abstract}

Key words: Demographic Variables, Educational Qualification, Consumer Purchase Decision, Need Recognition

\section{Introduction}

Demography is the study of the vital and measurable statistics of a population (Schiffman and Leslie, 2004). The demographic variables are age, gender, marital status, family size, family life cycle, income, occupation, education, religion, race, generation, nationality and social class (Kotler, 2003). Demographics are used to describe a population in terms of its size, distribution and structure. Size means the number of individuals in a population while structure describes the population in terms of age, income, education and occupation. Distribution of the population describes the location of individuals in terms of geographic regions and rural, urban or suburban locations. Each of these factors influences the behaviour of consumer and contributes to the overall demand for various products and services (Hawkins, 1995). Schiffman and Kanuk (2004) define Consumer behaviour as the behavior that consumers display in searching for, purchasing, using, evaluating and disposing of products and services that they expect will satisfy their needs. Consumer buying behavior incorporates the acts of individuals directly involved in obtaining, using and disposing of economic goods and services including the decision process that precede and determine these acts (Huctings 1995). Lamb, Hair and McDaniel (1992) note that consumer behaviour is a study of the processes the consumer uses to make purchase decisions as well as the use and disposal of the purchased goods or services. It also includes the analysis of factors that influence purchase decisions and good/service usage. Further, it is important to note that consumer behavior is a process and purchase is only one stage in that process.

\section{Conceptual Framework}

Like psychological and social variables, demographic variables are also considered as the personal buying decision variables (Adcock, Bradfield, Halbord and Ross 1998). Barry (1986) defines demography as the study of population characteristics. These characteristics describe people - who are there, where they live, and where they are moving. Evans and Berman (1984) state demographics are easily identifiable and measurable statistics that are used to describe the population. Trends in population size indicate future potential and thus, influence market plans. The size of the population indicates the potential market demand for consumer products and services. Oldroyd (1989) notes demography is an important demand condition, helping the marketer to predict both size and change in target markets. Demographic factors have a bearing on the types of product which individuals want where they shop and how they evaluate possible purchases (Lancaster and Massingham 1998).

Marketers combine demographic, social and psychological data and study consumer decision making in order to better understand the consumers. These dimensions help to explain consumer life styles; the ways the people live. By understanding consumers, a firm is able to determine the most appropriate audience whom to appeal and the combination of a marketing factors that will satisfy this audience. So, it is imperative for marketers to use demographic data in conjunction with and part of social, psychological and consumer decisionmaking analyses. Evans and Berman (1984) claim that a person's demographic background has a strong 
influence in the life style or in the way of living adopted. The demographic information helps to locate a target market whose motives and behavior can then be explained and predicted using psychological or social cultural investigation. Demographic information identifies potential for sales and consumption of product although it does not identify why or by whom a particular brand is used. It is also relatively accessible and cost-effective to gather. Further, the demographic variables reveal trends relevant to marketers such as shifts in age and income distributions, etc. They can establish consumer profiles that may present attractive market opportunities. These are the causes why marketers, in growing numbers, are using demographic statistics for developing marketing strategies and programmes.

Consumer behavior is not just making a purchase decision or the act of purchasing; it includes the full range of experiences associated with using or consuming products and services. It also includes a sense of pleasure and satisfaction derived from possessing or collecting 'things'. The outputs of consumption are changes in feelings, moods, or attitudes; reinforcement in lifestyles; an enhanced sense of self; satisfaction of a consumer-related need; belonging to groups; and expressing and entertaining oneself. A consumer's decision to purchase or not to purchase a product or service is an important moment for most marketers. It can signify whether a marketing strategy has been wise, insightful, and effective, or whether it was poorly planned and missed the mark. Thus, marketers are particularly interested in the consumer's decision-making process. For a consumer to make a decision, more than one alternative must be available. In executing a purchase intention, the consumer may make up to five purchase sub decisions: a brand decision, vendor decision, quantity decision, timing decision and payment - method decision (Kotler, Philip2003).

\subsection{Need Recognition:}

The buying process starts where the buyer recognizes a problem or need. The need may be triggered by internal or external stimuli. Everyone has unsatisfied needs and wants that create tension or discomfort. Some needs can be satisfied by acquiring and consuming goods and services. Thus, the process of deciding what to buy begins when a need, which can be satisfied through consumption, becomes strong enough to motivate a person. Mahatoo (1985) states that when the consumer becomes aware of a discrepancy between the existing state and a desired state, need is aroused. The existing state is the total situation of a consumer: the current needs, attitudes, and motives; the desired state is the situation after the kinds of changes the consumer wishes. The existing state and the desired state are the functions of the consumer's motivation, personality, and past experience of cultural and social influences and of past marketing stimuli. Evans and Berman (1984) define a stimulus as a cue intended to motivate a person to act. It may be social, commercial, noncommercial or an inner drive. Need recognition signifies a person's readiness to act. Becoming aware of a need does not guarantee that the decision making process will continue. Only if the problem is important to the consumer and he or she believes that a solution is available will it continue (Baker 2000). Kotler (2003) suggests that, by gathering information from a number of consumers, marketers can identify the most frequent stimuli that spark an interest in a product category. They can then develop marketing strategies that trigger consumer interest.

\subsection{Education:}

Education is a powerful influence on consumer behavior; the level of literacy in specific areas and regions may provide marketers with opportunities to sell sophisticated products and services. Higher education gives entry to the professions; social aspiration and consumption levels are raised (Chisnall, 1994). As the population of a society gets more educated it become more sophisticated in its buying behavior. Marketers must adjust to that increasing level of consumer sophistication (Barry 1986). With an increasing number of people attaining higher levels of education, marketers can expect to see i) changes in product preferences and ii) buyers with higher incomes and more discriminating tastes (Stanton, Etzel and Walker 1994).

\section{Literature Review}

Everyone has unsatisfied needs and wants that create tension or discomfort. Some needs can be satisfied by acquiring and consuming goods and services. Thus, the process of deciding what to buy begins when a need, which can be satisfied through consumption, becomes strong enough to motivate a person. Mahatoo (1985) states that when the consumer becomes aware of a discrepancy between the existing state and a desired state, need is aroused. The existing state is the total situation of a consumer: the current needs, attitudes, and motives; the desired state is the situation after the kinds of changes the consumer wishes. The existing state and the desired state are the functions of the consumer's motivation, personality, and past experience of cultural and social influences and of past marketing stimuli. Evans and Berman (1984) define a stimulus as a cue intended to motivate a person to act. It may be social, commercial, noncommercial or an inner drive. Need recognition signifies a person's readiness to act. Becoming aware of a need does not guarantee that the decision making process will continue. Only if the problem is important to the consumer and he or she believes that a solution is available will it continue (Baker 2000). Kotler (2003) suggests that, by gathering information from a 
number of consumers, marketers can identify the most frequent stimuli that spark an interest in a product category. They can then develop marketing strategies that trigger consumer interest.

Marketers need to identify the circumstances that trigger a particular need. Bruner (1987) points out that among the consumers, there seem to be two different need or problem recognition styles. Some consumers are actual state types, who perceive that they have a problem when a product fails to perform satisfactorily. In contrast, other consumers are desired state type, for whom the desire for something new may trigger the decision process. Zaltman and Wallendorf (1979) considered two major traditions in consumer behavior for building model for need recognition. The first tradition is Maslow's hierarchy needs. This theory suggests that needs can be prioritized in hierarchy and that consumers satisfy higher order needs before they satisfy those lower in the hierarchy. The second tradition is that McClelland theory which suggests that needs are learned. This approach emphasizes the importance of contextual variables in consumer choice. Bruner (1985) says that when faced with an imbalance between actual and desired states, an individual experiences problem recognition. The desired state, the individual would like to achieve, reflects a need. Reibstein (1985) points out that consumers recognize unfulfilled wants in the following ways: i) a currently used product or brand is not performing properly, ii) a buyer wants to do something but can't find a product that will do it, iii) a buyer hears about or sees a product whose features seem superior to the one currently used, iv) a buyer has difficulty in locating or purchasing a preferred product and v) a buyer in running out of a product that is generally kept on hand.

Bass, Tigert and Lonsdale (1968) conducted an extensive study and found that light and heavy users of ten product categories were different with respect to their income, educational level, marital status, occupation and number of children. Nielson Survey Report (2000) reveals that consumers with lower incomes, lower education, and blue-collar occupations tend to spend more time online at home than those with higher income, higher education and white-collar occupations. One possible reason for this difference is that those in bluecollar jobs often do not have access to the internet during the course of the workday. Forrester Research (2001) reports that affluent customers have an affinity for technology, especially when it comes to the task of managing their finances. Goldman (1999) defines middle class as households composed of college-educated adults who in some way use computers to make a living are involved in their children's education, and are confident that they can maintain the quality of their family's life.

\section{Research Methodology}

This study is descriptive in nature. The purpose of this study is to find out whether the educational qualification of consumers influence need recognition of consumer purchase decision process. For this purpose, primary data have been collected from 405 car owners who bought their car during the year 2010-11 in Chennai city. Simple random sampling method has been adopted for identifying samples from the population. A specific questionnaire was developed for the study and the same was used to collect data from the respondents. SPSS package has been used for analyzing the data using both one way ANOVA for establishing relationship between the educational qualification of consumers and need recognition.

\subsection{Ranking of factors influencing the Need Recognition:}

Weighted average method is used for ranking the various factors which influence the respondents in recognizing the need for a car. By knowing the significant factors, the car marketers could concentrate on those factors in order to create a need in the minds of the consumers to buy a car. The weighted average score and assigned ranks for the factors are given in the following table:

Table 1: Weighted Average Score for Ranking the Factors Influencing Need Recognition

\begin{tabular}{|l|c|c|c|c|c|c|}
\hline \multirow{2}{*}{\multicolumn{1}{c|}{ Factors }} & \multicolumn{2}{c|}{ Small Segment } & \multicolumn{2}{c|}{ Mid Segment } & \multicolumn{2}{c|}{ Premium Segment } \\
\cline { 2 - 7 } & $\begin{array}{c}\text { Weighted } \\
\text { Average }\end{array}$ & $\begin{array}{c}\text { Assigned } \\
\text { Rank }\end{array}$ & $\begin{array}{c}\text { Weighted } \\
\text { Average }\end{array}$ & $\begin{array}{c}\text { Assigned } \\
\text { Rank }\end{array}$ & $\begin{array}{c}\text { Weighted } \\
\text { Average }\end{array}$ & $\begin{array}{c}\text { Assigned } \\
\text { Rank }\end{array}$ \\
\hline Social Status & 62.87 & 6 & 23.13 & 5 & 12.27 & 6 \\
\hline Family Necessity & 77.67 & 1 & 27.33 & 2 & 13.60 & 2 \\
\hline Business Convenience / status & 67.73 & 4 & 26.60 & 3 & 12.93 & 4 \\
\hline Comfort \& Convenience & 74.93 & 2 & 27.93 & 1 & 13.27 & 3 \\
\hline Availability of Loans for Purchase & 58.07 & 7 & 17.00 & 12 & 10.00 & 12 \\
\hline Advertisement \& Its Impact & 51.13 & 10 & 19.13 & 9 & 11.27 & 9 \\
\hline Offer / Discount Availability & 49.33 & 11 & 18.27 & 10 & 10.13 & 11 \\
\hline Easy Instalment Schemes & 52.20 & 9 & 18.13 & 11 & 10.73 & 10 \\
\hline Publicity \& Personal Selling & 48.93 & 12 & 19.67 & 8 & 11.80 & 8 \\
\hline Symbol of Success & 55.53 & 8 & 21.93 & 7 & 13.87 & 1 \\
\hline Economy of Purchase / Use & 64.47 & 5 & 23.07 & 6 & 12.20 & 7 \\
\hline Transportation Requirement & 74.33 & 3 & 24.67 & 4 & 12.53 & 5 \\
\hline
\end{tabular}

Source: Primary Data 
The Table 1 shows the weighted average score for the various factors which influence the respondents recognition of the need for buying a car. As far as the small segment is concerned, the highest weighted average score is 77.69 for family necessity which is ranked first and followed by comfort and convenience (74.93), transportation requirement (74.33), business convenience and status (67.73), economy of purchase/use (64.47) etc., and the least weighted average score is 48.93 for publicity and personal selling.

\subsection{The role of Educational Qualification of the respondents on Need Recognition:}

One way analysis of variance is used to test the following the hypothesis:

Ho: There is no significant difference among the various educational qualifications of respondents with regard to the level of need recognition.

Table 2: One Way Analysis of Variance among the Various Educational Qualifications of Respondents With Regard to Need Recognition

\begin{tabular}{|c|c|c|c|c|c|c|}
\hline S. No. & Segments & Df & SS & MS & $\overline{\mathbf{X}}$ & $\begin{array}{l}\text { Statistical } \\
\text { Inference }\end{array}$ \\
\hline 1 & $\begin{array}{l}\text { Small Segment } \\
\text { Between Groups } \\
\text { Within Groups }\end{array}$ & $\begin{array}{c}3 \\
262\end{array}$ & $\begin{array}{c}433.781 \\
10986.083\end{array}$ & $\begin{array}{l}144.594 \\
41.932\end{array}$ & $\begin{aligned} \mathrm{G} 1 & =43.00 \\
\mathrm{G} 2 & =43.10 \\
\mathrm{G} 3 & =42.20 \\
\mathrm{G} 4 & =36.91\end{aligned}$ & $\begin{array}{c}\mathrm{F}=3.448 \\
\mathrm{P}<0.05 \\
\text { Significant }\end{array}$ \\
\hline 2 & $\begin{array}{l}\text { Mid Segment } \\
\text { Between Groups } \\
\text { Within Groups }\end{array}$ & $\begin{array}{l}2 \\
90\end{array}$ & $\begin{array}{r}393.457 \\
4186.435\end{array}$ & $\begin{array}{r}196.729 \\
46.516\end{array}$ & $\begin{aligned} \mathrm{G} 1 & =43.84 \\
\mathrm{G} 2 & =42.61 \\
\mathrm{G} 3 & =48.36 \\
\mathrm{G} 4 & =40.54\end{aligned}$ & $\begin{array}{c}\mathrm{F}=4.229 \\
\mathrm{P}<0.05 \\
\text { Significant }\end{array}$ \\
\hline 3 & $\begin{array}{l}\text { Premium Segment } \\
\text { Between Groups } \\
\text { Within Groups }\end{array}$ & $\begin{array}{c}2 \\
43\end{array}$ & $\begin{array}{l}546.155 \\
2415.780\end{array}$ & $\begin{array}{c}273.078 \\
56.181\end{array}$ & $\begin{aligned} \mathrm{G} 1 & =49.66 \\
\mathrm{G} 2 & =45.20 \\
\mathrm{G} 3 & =57.21 \\
\mathrm{G} 4 & =42.74\end{aligned}$ & $\begin{array}{c}\mathrm{F}=4.861 \\
\mathrm{P}<0.05 \\
\text { Significant }\end{array}$ \\
\hline
\end{tabular}

The Table 2 indicates that there is a significant difference among the various educational qualifications of small car owners with regard to their level of need recognition and Ho is rejected. Further, the mean score reveals that the car owners who are graduates, experience a higher level of need recognition than the other groups.With regard to the mid and premium segments, there is a significant difference among the various educational qualifications of respondents with regard to their level of need recognition and Ho is accepted. Further, the mean score reveals that the midsized and premium car owners who have completed their post graduation degree, experience a higher level of need recognition than the other groups.

\section{Conclusion}

Demographics are uncontrollable variables in the external environment. Hence, studying the population in terms of its demographic structure is very significant for marketing managers in the prevailing competitive scenario. The relationship established between educational qualification and need recognition of consumers would further help the marketers understand the target group and evolve marketing strategies to make them buy their brands.

\section{Acknowledgement}

The author sincerely thank Dr.S.Kaliyamoorthy, Professor and Director, Alagappa Institute of Management, Alagappa University, Prof.S.Joseph Jeya Anand, Assistant Professor, VIT Business School, VIT University and Mr.S.Alwin Reginald for their help and guidance in carrying out this study successfully. 


\section{References}

[1]. Adcock, Dennis, Ray Bradfield, Al Halbord and Caroline Ross, (1998), Marketing Principles and Practice, $3^{\text {rd }}$ ed., Financial Times Pitman Publishing: USA, pp 61-69.

[2]. Baker, Michael J (2000), The Marketing Book, $4^{\text {th }}$ ed., Butterworth - Heinemann: UK, p 112.

[3]. Barry, Thomas (1986), Marketing - An Integrated Approach, The Dryden Press: USA, pp $127-162$

[4]. Bass, Frank M., Dougles J. Tigert and Ronald T. Lonsdate (1968), "Market Segmentation: Group Versus Individual Behavior", Journal of Marketing Research, 5, (August), pp 264-270.

[5]. Bruner, Gordon (1985), "Recent Contributions to the theory of problem Recognition", in: AMA Education Proceedings, Robert Lunch et. al. (eds), American Marketing Association: Chicago, pp11-15.

[6]. Bruner, Gordon C. (1987), "The effect of Problem Recognition style an Information Seeking", Journal of the Academy of Marketing Science, Vol.15, Winter, pp 33-41.

[7]. Chisnall, Peter M. (1994), Consumer Behaviour, $3^{\text {rd }}$ ed., McGraw Hill Book Company: London, pp 168-170.

[8]. Evans, Joel R. and Barry Berman (1984), Essentials of Marketing, Macmillan, USA, pp 78-104.

[9]. Goldman, Debera (1999), "Paradox of Pleasure", American Demographics, May, pp 50-53

[10]. Hawkins, Del I, Roger I. Best and Kenneth A. Coney (1995), "Consumer Behaviour - Implications for Marketing Strategy", 6 th ed., Irwin Publishers, p 78

[11]. Hutchings, Andy (1995), Marketing - A Resource Book, $1^{\text {st }}$ ed., Pitman Publishing: UK.,pp 67-75.

[12]. Kotler, Philip (2003), Marketing Management, $112^{\text {th }}$ ed., Pearson Education Asia, pp 183-203.

[13]. Lamb, Charles W. Jr., Joseph F Hair and Carl McDaniel (1992), Principles of Marketing, South - Western Publishing Co.: Ohio, pp 71-84.

[14]. Lancaster, Geff and Lester Massingham (1998), Essentials of Marketing, McGraw Hill Publishing Company: U.K., pp 51-66.

[15]. Mahatoo, Winston H (1985), The Dynamics of Consumer Behaviour, John Weley\& Sons Canada Ltd.: Toronto, Ontario, pp 5-8.

[16]. "New Forrester Report Advices How to Win Affluent Consumers in the Economic Slump", Business Wire, August 1, 2001.

[17]. Nielson Net Ratings (2000), "Less Well - To - Do Web Surfers Spend More Time Online Than More Affluent People", Business Wire, September 21, p 1

[18]. Oldroyd, Mike (1999), CIM Work Book - Marketing Environment, $4^{\text {th }}$ ed., Butterworth - Heinemann: UK, pp. 185-200.

[19]. Reibstein, David (1985), Marketing: Concepts, Strategies and Decisions, Engle Wood Cliffs, Prentice Hall: New Jersey, p146.

[20]. Schiffman, Leon G. and Leslie LazerKanuk (2004), ConsumebrBehaviour, $8^{\text {th }}$ ed., Prentice Hall of India Pvt. Ltd.: New Delhi, p 8.

[21]. Stanton, William J., Michael J. Etzel and Bruce J. Walker (1994), Fundamentals of Marketing, 10 ${ }^{\text {th }}$ ed., McGraw Hill Inc.: Singapore, pp $129-136$.

[22]. Zaltman, G. and Wallendorf. M. (1979), Consumer Behavior: Basic Findings and Management Implications, John Wiley: New York. 